The problem of girls between fourteen and sixteen, who are employed in stores and factories, is one which gives more and more anxiety to Wisconsin students of social problems. We hope that the hours of work for girls up to twenty-one may be shortened at the next session of the legislature, so that at the least some undesirable employments will be closed to them and that compelling their dismissal from work at an early hour may avoid some of the evils resulting, in part at least, from young girls leaving work at the same hour as the men do.

The Wisconsin committee is convinced that child labor laws standing by themselves, even if thorough and modern in form, are too often a mockery of legislation unless they are accompanied by satisfactory and thoroughly enforced education and truancy laws and by ungraded rooms and schools, playgrounds and park facilities, and in general, unless when employment is denied to children, school and vacation facilities are given and school attendance compelled. Our committee therefore seeks not only a child labor law which shall be practical and modern in the best sense, but also to keep fully abreast (and if possible in advance of that standard) the educational system of the state, including compulsory education laws and satisfactory truancy laws. And we believe that the juvenile court should be extended throughout the state. Undesirable as certain forms of child labor are, and much as we may look forward to a time when no child under sixteen shall be employed at gainful occupations the fact remains that under existing conditions a great number of such children must work for wages, and that it is far worse to have children in idleness on the streets, studying in the school of crime, because of lack of proper educational laws and of vacation schools and playgrounds and other proper and normal ways to use the abounding strength of childhood.

Edward W. Frost, Chairman.

\title{
REPORT OF THE PENNSYLVANIA CHILD LABOR COMMITTEE
}

During the past year the Pennsylvania Child Labor Committee has been engaged actively in a campaign for the enforcement of the child labor law.

Eighty-three cases were reported to the chief factory inspector and twenty to deputies of the factory department, in which the committee alleged violations of the law; as a result of this information $\$ 11,500$ in fines was imposed. Nine prosecutions were brought and seven were successful. One hundred and sixty children were discovered by the committee to be illegally employed, and sixty-nine of them were dismissed.

In addition to this work the committee distributed forty thousand circulars, pamphlets, copies of the law, etc.

During the summer the two most important sections of the Pennsylvania child labor law, those relating to the employment certificate were declared unconstitutional, and it is now incumbent upon the committee to secure a new law covering the defects which the court found in the old one.

Scoti Nearing, Secretary. 